\section{Anti-Listeria activity of lactic acid bacteria in two traditional Sicilian cheeses}

\author{
Maria Luisa Scatassa, \\ Raimondo Gaglio, ${ }^{1,2}$ \\ Cinzia Cardamone, ${ }^{1}$ Giusi Macaluso, ${ }^{1}$ \\ Luigi Arcuri, ${ }^{3}$ Massimo Todaro, ${ }^{2}$ \\ Isabella Mancuso ${ }^{1}$ \\ ${ }^{1}$ Institute for Experimental Veterinary \\ Medicine of Sicily, Palermo; \\ ${ }^{2}$ Department of Agricultural and Forest \\ Sciences, University of Palermo, \\ Palermo; ${ }^{3}$ Local Health Unit, Palermo, \\ Italy
}

\begin{abstract}
Listeria monocytogenes is a pathogen frequently found in dairy products, and its growth is difficult to control. Bacteriocinlike inhibitory substances (BLIS), produced by lactic acid bacteria (LAB), having proven in vitro anti-Listeria activity, could provide an innovative approach to control L. monocytogenes; however, this application needs to be evaluated in vivo. In this study, twenty LAB strains isolated from different Sicilian dairy environments were tested for control of growth of L. monocytogenes in three different experimental trials. First, raw and UHT milk were inoculated with LAB strains alone, and LAB strains mixed with L. monocytogenes. Second, mini-cheeses containing LAB and/or $L$. monocytogenes were produced. Third, two traditional Sicilian cheeses inoculated with a multi-strain LAB mixture combined with L. monocytogenes were produced. The addition of BLIS produced by LAB to milk and in mini-cheese production was unable to inhibit the growth of $L$. monocytogenes. However, an anti-Listeria effect was observed in the Pecorino Siciliano cheeses, where, after 15 days of ripening, the cheeses with added LAB had fewer $L$. monocytogenes compared to the control cheeses with no added LAB, while in the Vastedda della valle del Belice cheeses, the multi-strain LAB mixture completely prevented the growth of $L$. monocytogenes.
\end{abstract}

\section{Introduction}

Foodborne diseases are among the most serious and costly public health concerns worldwide (WHO/FNU/FOS, 1995). Listeria monocytogenes is the causative agent of listeriosis, a foodborne disease that causes life-threatening infections in the elderly, pregnant women, newborn babies, and immunocompromised people. This pathogen is present in a range of foods, including dairy products (Fretz et al., 2010; Koch et al., 2010). The ability of L. monocytogenes to survive exposure to diverse adverse conditions, including acidic $\mathrm{pH}$, low temperatures, and high sodium chloride concentrations, make this organism difficult to control in food (Farber and Peterkin, 1991). Bacteriocins produced by lactic acid bacteria (LAB) are able to prevent the growth of undesired bacteria, included $L$. monocytogenes (Scatassa et al., 2015); hence, they have been extensively tested for food applications (Gálvez et al., 2008). In this context, the use of bacteriocinogenic LAB strains as starter or co-cultures is a promising strategy to improve cheese hygiene conditions (Settanni and Moschetti, 2014). This interest is based on several properties that make them good candidates for food preservation provided their acceptance by food regulations. LAB bacteriocins are defined Generally Recognized As Safe (GRAS) substances, since they are produced by food-grade microorganisms that have been consumed for centuries (Cotter et al., 2005). Furthermore, they show no activity or toxicity on eukaryotic cells and are inactivated by digestive proteases, ensuring little influence on gut microbiota (Bernbom et al., 2006). Some studies have reported the use of bacteriocin produced by LAB for biopreservation of cheeses (Hernández et al., 2005; O'Sullivan et al., 2006). The products of LAB catabolism are not only useful for cheese preservation, but also contribute to its flavour, aroma, and texture, thereby helping to determine unique product characteristics (Monfredini et al., 2012; Guarcello et al., 2016).

This work was performed to characterize the bacteriocinogenic activities of LAB strains isolated from different Sicilian dairy environments, and to evaluate their antiListeria potential during the production of two traditional Sicilian cheeses: Pecorino Siciliano (PS) and Vastedda della valle del Belice (VB).

\section{Materials and Methods}

\section{Antimicrobial activity assay}

Twenty LAB strains (Table 1) were selected from a total of 37 strains isolated from different Sicilian dairy environments, based on their production of antimicrobial substances (Macaluso et al., 2016), and thus their technological relevance in cheese making. The 20 strains were representative
Correspondence: Maria Luisa Scatassa, Institute for Experimental Veterinary Medicine of Sicily "A. Mirri”, via Gino Marinuzzi 3, 90129 Palermo, Italy. Tel: +39.091.6565300 - Fax: +39.091.6565332. E-mail: luisa.scatassa@izssicilia.it

Key words: BLIS; Milk; In vivo applications; Listeria monocytogenes; Traditional Sicilian cheeses.

Conflict of interest: the authors declare no potential conflict of interest.

Funding: this work was supported by the Italian Ministry of Health Research Project RC 06/12 Batteri lattici produttori di batteriocine isolati da formaggi tradizionali: valutazione in vivo dell'attività inibente ai fini della sicurezza alimentare.

Acknowledgments: the authors would like to thank V. Alio, A. Carrozzo, B. Ducato and L. Nicastro for their precious collaboration.

Received for publication: 22 July 2016. Revision received: 30 November 2016. Accepted for publication: 7 December 2016.

This work is licensed under a Creative Commons Attribution-NonCommercial 4.0 International License (CC BY-NC 4.0).

CC Copyright M.L. Scatassa et al., 2017

Licensee PAGEPress, Italy

Italian Journal of Food Safety 2017; 6:6191

doi:10.4081/ijfs.2017.6191

of different $\mathrm{LAB}$ species and isolation sources. The antimicrobial activity of these 20 strains was evaluated against eight strains of L. monocytogenes of food origin (LM 2011/2/3 - LM 2013/4/3 - LM 2013/6/4 - LM 2014/7/4 from smoked salmon; LM 2012/8/123 - LM 2012/3/45 LM 2014/5/43 from salami and LM 2013/1/3 from cheese) obtained from the culture collection of Institute for Experimental Veterinary Medicine of Sicily, Palermo, Italy. The antimicrobial activity of LAB strains was initially detected by the spot-on-the lawn method, and the strains showing positive results were subsequently tested by the well diffusion assay (WDA) (Schillinger and Lücke, 1989; Corsetti et al., 2008), which is based on the diffusion of the antimicrobial substances in the culture medium, and indicates inhibitory activity against an indicator strain by the detection of an inhibition halo around the colony. The sensitivity of the active supernatants to proteolytic enzymes was tested by digesting them with proteinase $\mathrm{K}\left(12.5 \mathrm{U}_{\mathrm{mg}}^{-1}\right)$, protease B (45 U.mg ${ }^{-1}$ ) and trypsin (10.6 U.mg-1) at a final concentration of 1 $\mathrm{mg} \cdot \mathrm{mL}^{-1}$ in phosphate buffer $(\mathrm{pH}$ 7.0). After 
incubating for $2 \mathrm{~h}$ at $37^{\circ} \mathrm{C}$, the remaining activity was measured by a second WDA (Settanni et al., 2005).

\section{In vivo application}

In order to evaluate the in vivo inhibitory activity of the LAB strains in cheese proand multi-strain combinations with 'mix 1', containing Lactococcus lactis (992), Lactobacillus rhamnosus (623) and Enterococcus faecium (971), which were chosen for their potential to preserve the sensory profile and structural characteristics typical to each cheese (Mancuso et al., 2016).

The anti-Listeria activity of the LAB strains was tested in three different experimental trials. In the first trial, raw and UHT milk was inoculated with LAB in single, and with mix 1 in combination with $L$. monocytogenes. The milk was incubated at $37^{\circ} \mathrm{C}$ for $10-13 \mathrm{~h}$ until the value reached the range of 5.5. In the second trial, 10 minicheeses were produced with 2 L of pasteurised milk inoculated individually with combinations of $\mathrm{LAB} / L$. monocytogenes. In the final trial, two traditional Sicilian cheeses (PS and VB) were produced with $10 \mathrm{~L}$ each of ewe's raw milk inoculated with a combination of mix 1 and L. monocytogenes at experimental dairy level in standard conditions in order to keep all process variables constant. A control cheese of each type, inoculated with $L$. monocytogenes ATCC 7644 at about $10^{4} \mathrm{CFU} / \mathrm{mL}$, was included for comparison (denoted as PS1 and VB1).

All LAB were initially cultured in de Man-Rogosa-Sharpe (MRS) and M17 broth for $24 \mathrm{~h}$ at $30^{\circ} \mathrm{C}$, while L. monocytogenes was refreshed in Brain Heart Infusion (BHI) broth at $37^{\circ} \mathrm{C}$ for $18-24 \mathrm{~h}$, and thereafter streaked onto selective Agar Listeria acc. Ottaviani \& Agosti (ALOA) plates to assess purity. After propagation in broth, both $\mathrm{LAB}$ and $L$. monocytogenes were centrifuged at $10,000 \times \mathrm{g}$ for $5 \mathrm{~min}$, washed in Ringer's solution and re-suspended in the same solution to achieve an optical density (OD) of ca. 1.00, measured by 6400 Spectrophotometer (Jenway Ltd., Felsted Dunmow, UK) at $600 \mathrm{~nm}$ wavelength, which approximately corresponds to a concentration of $10^{9} \mathrm{CFU} / \mathrm{mL}$, to standardize bacterial inocula (Settanni et al., 2014). Cell suspensions were inoculated into milk during cheeses production (trial 2 and 3 ) at a final concentration of approximately $10^{7}$ $\mathrm{CFU} / \mathrm{mL}$ of $\mathrm{LAB}$ as a starter cultures, while L. monocytogenes ATCC 7644 was inoculated at about $10^{4} \mathrm{CFU} / \mathrm{mL}$ to simulate massive contamination. In trial 1 , raw and UHT milk were inoculated at about $10^{2}-10^{4}$ duction, these strains were tested in single
$\mathrm{CFU} / \mathrm{mL}$ of L. monocytogenes and approximately $10^{7} \mathrm{CFU} / \mathrm{mL}$ of LAB.

\section{Cheese production}

The mini-cheeses were produced using $2 \mathrm{~L}$ of pasteurized milk, without cooking the curd under hot whey and dry salting in order to minimize the inhibition of $L$. monocytogenes due to biocompetition, heat treatment, and acid fermentation.

Cheese making trials were carried out in a dairy pilot plant (Institute for Experimental Veterinary Medicine of Sicily "Adelmo Mirri", Palermo, Italy) using the POLYFOOD mod. SI-050 (INVENTAGRITM, Modena, Italy). PS and VB cheeses were produced following traditional protocols (Figure 1), except for the use of wooden equipment. In both cheeses, raw ewe's milk was inoculated with a combination of mix 1 and L. monocytogenes. The cheeses were produced in duplicate at one-month intervals in the spring and summer season (first week of June-first week of July) 2016.

\section{Microbial analysis}

Microbiological analysis was carried out to evaluate the concentrations of the combined $\mathrm{LAB} / L$. monocytogenes culture in experimental cheese production (trial 2 and 3), and the concentration of L. monocy-

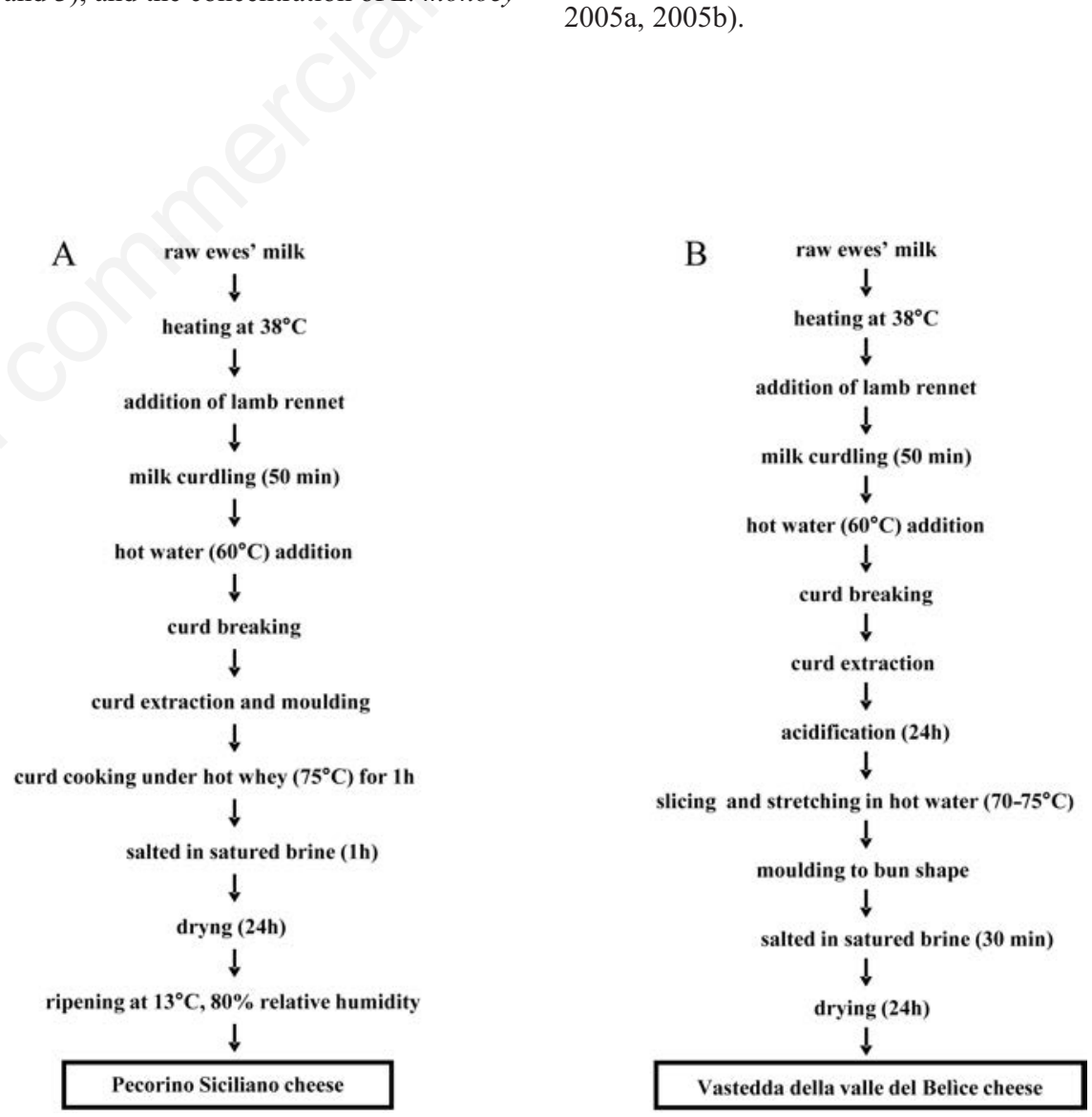

Figure 1. Flow diagram of Pecorino Siciliano cheese production (A) and protected designation of origin Vastedda della valle del Belice cheese production (B).

togenes in trial 1.

In trial 3, for the PS, curds were collected soon after transfer into perforated containers for analysis, while the cheeses were analysed after one day of drying following salting in saturated brine $\left(\mathrm{t}_{0}\right)$, and after 15 days of ripening $\left(\mathrm{t}_{15}\right)$ at $13^{\circ} \mathrm{C}$.

In the case of the VB, curds were collected soon after transfer into perforated containers and before stretching (acidified curds). The final cheeses were analysed after one day of drying following salting in saturated brine $\left(\mathrm{t}_{0}\right)$, and after 15 days of refrigerated storage under vacuum $\left(t_{15}\right)$. Cell suspensions of solid samples (25 $\mathrm{g}$ each of curd and cheese) were first homogenized in a stomacher (400 Circulator Bags; Seward, AK, USA) for $10 \mathrm{~min}$ at $260 \mathrm{rpm}$, and then serially diluted. Presumptive rod LAB were grown on MRS agar, acidified to $\mathrm{pH} 5.4$ with lactic acid $\left(5 \mathrm{~mol} \mathrm{~L}^{-1}\right)$, incubated anaerobically for $72 \mathrm{~h}$ at 30 and $44^{\circ} \mathrm{C}$, respectively; while presumptive coccus $\mathrm{LAB}$ were grown on M17 agar, incubated aerobically for $48 \mathrm{~h}$ at 30 and $44^{\circ} \mathrm{C}$, respectively. Detection and enumeration of L. monocytogenes was carried out on milk, $25 \mathrm{~g}$ of curd and cheese sample, on ALOA, following the UNI EN ISO 11290-1:2005 and UNI EN ISO 11290-2:2005, respectively (ISO, 2005a, 2005b). 


\section{Results and Discussion}

\section{Antimicrobial activity assay}

All 20 LAB strains exhibited similar antibacterial activity, inhibiting L. monocytogenes ATCC 7644 (Macaluso et al., 2016) and eight L. monocytogenes of food origin, showing an inhibition halo between 5 and 7 $\mathrm{mm}$. Treating the culture supernatants with proteolytic enzymes eliminated all inhibitory activity, confirming that the toxins were proteinaceous in nature. Because we did not characterize the amino acid and nucleotide sequences for these substances in this study, we will be referring to them generally as BLIS (Corsetti et al., 2008). The capacity of our LAB strains to produce BLIS represents a positive attribute that ensures a competitive advantage in the control of undesirable microbial populations.

\section{In vivo application and microbial analysis}

Considering that $L$. monocytogenes can survive in cheeses during manufacture, ripening, and storage under refrigeration (Morgan et al., 2001), the control of growth is a challenge for producers and consumers.

In accordance with previously published literature (Schillinger et al., 1996), our results did not show a reduction in the growth of the pathogen in raw and UHT milk or in mini-cheeses, which demonstrates that the efficacy of bacteriocins in culture media is not always reproducible in food systems (in vivo).

To this purpose, the anti-Listeria activity of the LAB strains was tested in multistain combination for cheese production at pilot plant level as reported Callon et al. (2011). Changes in the levels of concentration of L. monocytogenes, mesophilic and thermophilic rod and coccus LAB during the two traditional production are reported in Table 2.

After inoculation, the raw ewe's milk had 7.32-7.48 $\log \mathrm{CFU} / \mathrm{mL}$ of LAB and $4.88 \log \mathrm{CFU} / \mathrm{mL}$ of L. monocytogenes, whose concentration was affected by the addition of LAB and the pathogen. All cheeses had increased LAB concentrations of at least $1 \mathrm{log}$. Furthermore, all cheeses were dominated by growth of LAB and the differences between control and experimental cheeses were less evident in this population. However, the amount of L. monocytogenes in both experimental cheeses was reduced by approximately $3 \log$ for PS, while it remained undetectable for VB. The addition of LAB strains caused a rapid decrease of the detectable pathogen in acidified curd, with $2.54 \log$ CFU/g measured in $\mathrm{VB}$, while $4.30 \log \mathrm{CFU} / \mathrm{g}$ was detected in the control VB1.

A significant reduction in the CFU/g of L. monocytogenes caused by BLIS produced by LAB has been reported for

camembert cheese (Maisnier-Patin et al., 1992) and cheddar cheese (Buyong et al., 1998), whereas no previous study has evaluated the inhibitory effect of selected

Table 1. Strains used in this study.

\begin{tabular}{lcc} 
Strains & \multicolumn{1}{c}{ Species } & Origin \\
150 & Lactobacillus casei & Pecorino cheese \\
153 & Leuconostoc mesenteroides & Raw ewe's milk \\
\hline 623 & Lactobacillus rhamnosus & Caciocavallo Palermitano cheese \\
971 & Enterococcus faecium & Wooden vat surfaces (cow's cheese) \\
\hline 979 & Enterococcus faecium & Wooden vat surfaces (cow's cheese) \\
981 & Lactococcus lactis & Wooden vat surfaces (cow's cheese) \\
\hline 983 & Streptococcus thermophilus & Wooden vat surfaces (cow's cheese) \\
986 & Enterococcus faecium & Wooden vat surfaces (ewe's cheese) \\
\hline 990 & Enterococcus faecium & Wooden vat surfaces (ewe's cheese) \\
991 & Enterococcus faecium & Wooden vat surfaces (ewe's cheese) \\
\hline 992 & Lactococcus lactis & Wooden vat surfaces (ewe's cheese) \\
993 & Leuconostoc mesenteroides & Wooden vat surfaces (cow's cheese) \\
\hline 995 & Leuconostoc mesenteroides & Wooden vat surfaces (cow's cheese) \\
996 & Leuconostoc mesenteroides & Wooden vat surfaces (cow's cheese) \\
\hline 997 & Leuconostoc pseudomesenteroides & Wooden vat surfaces (cow's cheese) \\
999 & Lactobacillus delbrueckii & Wooden vat surfaces (cow's cheese) \\
\hline 1000 & Streptococcus thermophilus & Wooden vat surfaces (cow's cheese) \\
1001 & Enterococcus faecalis & Wooden vat surfaces (cow's cheese) \\
\hline 1008 & Enterococcus faecium & Wooden vat surfaces (cow's cheese) \\
1011 & Streptococcus thermophilus & Wooden vat surfaces (cow's cheese) \\
\hline & &
\end{tabular}

Table 2. Microbial loads of samples collected through experimental cheese production.

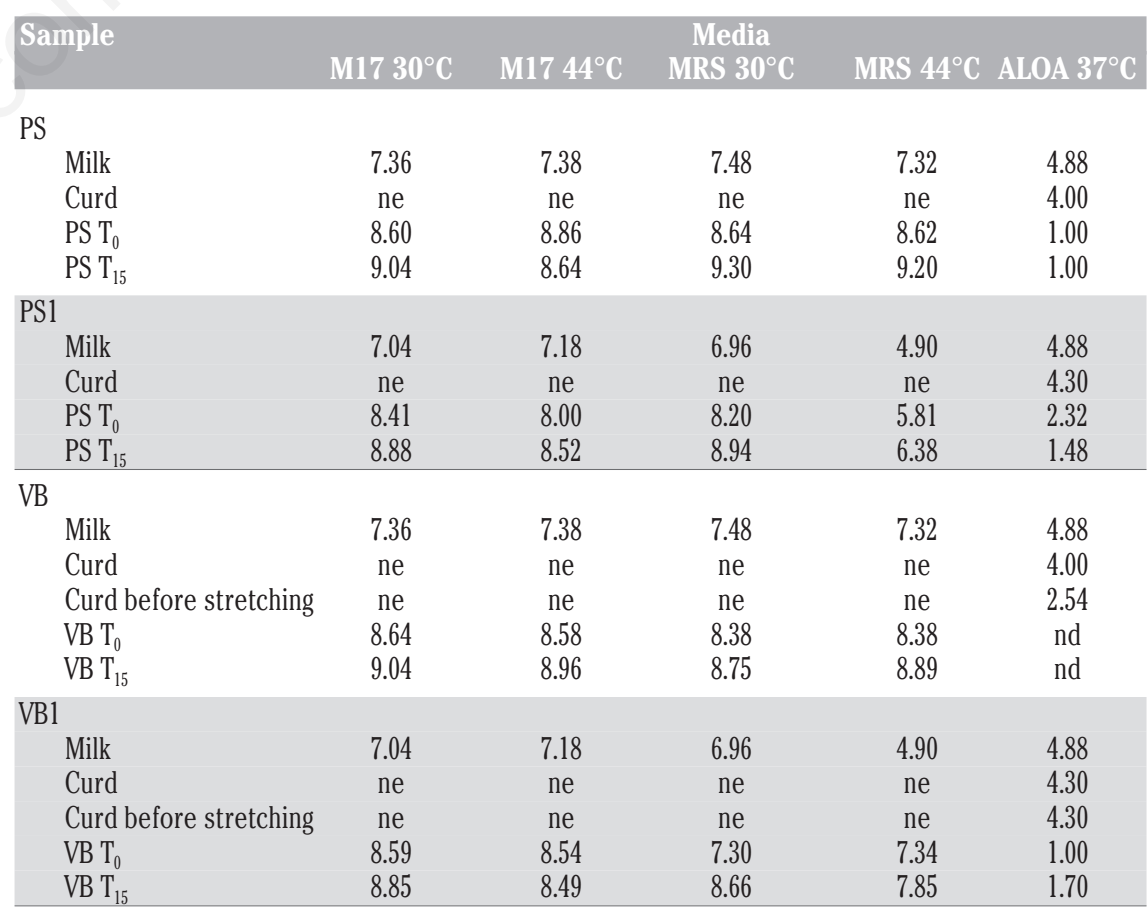

M17, agar for coccus lactic acid bacteria (LAB); MRS, de Man-Rogosa-Sharpe agar for rod LAB; ALOA, Agar Listeria acc. to Ottaviani \& Agosti for the detection of $L$. monocytogenes; PS, Pecorino Siciliano experimental production; PS1, Pecorino Siciliano control production; VB, Vastedda della valle del Belice experimental production; VB1, Vastedda della valle del Belice control production; ne, not evaluated; nd, not detected. 
autochthonous LAB on the growth of this pathogen in traditional Sicilian cheeses.

In control cheeses at $t_{15}$, L. monocytogenes was detected at $1.6 \log \mathrm{CFU} / \mathrm{g}$ and 1.7 $\log \mathrm{CFU} / \mathrm{g}$, respectively, for the controls PS1 and VB1. This indicates that the stressful conditions experienced during curd cooking under hot whey for the PS, and curd acidification and stretching in hot water for $\mathrm{VB}$, are not able to completely delete kill this pathogen. Furthermore, during the 15 days of refrigerated storage, $L$. monocytogenes in the VB1 cheese grew from $1.0 \log \mathrm{CFU} / \mathrm{g}$ to $1.7 \log \mathrm{CFU} / \mathrm{g}$, which highlights the ability of this pathogen to grow at low temperatures (Walker et al., 1990).

\section{Conclusions}

Sicilian dairy environments provide an appropriate ecological habitat for wild bacteriocin-producing LAB. The addition of BLIS produced by LAB to milk and minicheeses was not able to inhibit the growth of the pathogen L. monocytogenes. However, the addition of mixed LAB producers of BLIS (992 L. lactis, 623 L. rhamnosus and 971 E. faecium) to traditional PS and VB showed a broad spectrum of activity against L. monocytogenes. In particular, PS with added LAB showed a slight reduction in the number of CFU of the pathogen as compared to the control cheese, while in VB, the addition of LAB completely eliminated $L$. monocytogenes. This could be useful to prevent possible contamination of milk, cheese, or curd, and when producing cheese from raw milk. These results suggest that, with respect to PS and VB cheese production, the addition of autochthonous selected LAB is a good strategy to improve microbial quality, produce safer cheeses, and reduce risk to the consumers.

\section{References}

Bernbom N, Licht TR, Brogren CH, Jelle B, Johansen AH, Badiola I, Vogensen FK, Nørrung B, 2006. Effect of Lactococcus lactis on composition of intestinal microbiota: role of nisin. Appl Environ Microbiol 72:239-44.

Buyong N, Kok J, Luchansky JB, 1998. Use of a genetically enhanced, pediocin producing starter culture, Lactococcus lactis subsp. lactis MM217, to control Listeria monocytogenes in cheddar cheese. Appl Environ Microbiol 64:4842-5.

Callon C, Saubusse M, Didienne R,
Buchinet S, Montel MC, 2011. Simplification of a complex microbial antilisterial consortium to evaluate the contribution of its flora in uncooked pressed cheese. Int $\mathrm{J}$ Food Microbiol 145:379-89.

Corsetti A, Settanni L, Braga TM, de Fatima Silva Lopes M, Suzzi G, 2008. An investigation on the bacteriocinogenic potential of lactic acid bacteria associated with wheat (Triticum durum) kernels and non-conventional flours. LWTFood Sci Technol 41:1173-82.

Cotter PD, Hill C, Ross RP, 2005. Bacteriocins: developing innate immunity for food. Nat Rev Microbiol 3:77788.

Farber JM, Peterkin PI, 1991. Listeria monocytogenes, a food-borne pathogen. Microbiol Rev 55:476-511.

Fretz R, Pichler J, Sagel U, Much P, Ruppitsch W, Pietzka AT, Stöger A, Huhulescu S, Heuberger S, Appl G, Werber D, Stark K, Prager R, Flieger A, Karpísková R, Pfaff G, Allerberger F, 2010. Multinational listeriosis outbreak due to quargel, a sour milk curd cheese, caused by two different L. monocytogenes serotype 1/2a strains, 2009-2010. Euro Surveill 15:1-2.

Gálvez A, López RL, Abriouel H, Valdivia E, Omar NB, 2008. Application of bacteriocins in the control of foodborne pathogenic and spoilage bacteria. Crit Rev Biotechnol 28:125-52.

Guarcello R, Carpino S, Gaglio R, Pino A, Rapisarda T, Caggia C, Marino G, Randazzo CL, Settanni L, Todaro M, 2016. A large factory-scale application of selected autochthonous lactic acid bacteria for PDO Pecorino Siciliano cheese production. Food Microbiol 59:66-75.

Hernández D, Cardell E, Zárate V, 2005. Antimicrobial activity of lactic acid bacteria isolated from Tenerife cheese: initial characterization of plantaricin TF711, a bacteriocin $\square$ like substance produced by Lactobacillus plantarum TF711. J Appl Microbiol 99:77-84.

ISO, 2005a. Microbiology of food and animal feeding stuffs. Horizontal method for the detection and enumeration of Listeria monocytogenes. Part 1: Detection method. ISO Norm 112901:2005. International Standardization Organization, Geneva. Switzerland.

ISO, 2005b. ISO 11290-2:2005. Microbiology of food and animal feeding stuffs - Horizontal method for the detection and enumeration of Listeria monocytogenes - Part 2: Enumeration method. International Standardization Organization, Geneva. Switzerland.
Koch J, Dworak R, Prager R, Becker B, Brockmann S, Wicke A, WichmannSchauer H, Hof H, Werber D, Stark K, 2010. Large listeriosis outbreak linked to cheese made from pasteurized milk, Germany, 2006-2007. Foodborne Path Dis 7:1581-4.

Macaluso G, Fiorenza G, Gaglio R, Mancuso I, Scatassa ML, 2016. In vitro evaluation of bacteriocin-like inhibitory substances (BLIS) produced by lactic acid bacteria isolated during traditional Sicilian cheese making. Ital J Food Safety 5:20-2.

Mancuso, I, Gaglio, R, Carrozzo, A, Ducato, B, Arcuri, L, Scatassa, ML, 2016. [Valutazione attività inibente vs Listeria monocytogenes in formaggi prodotti con aggiunta di batteri lattici produttori di bacteriocin-like inhibitory substances (BLIS)]. Proc. 17th National Congress of the Italian Society of Veterinary Laboratory Diagnostics, Pacengo di Lazise (VR), 28-30 September 2016, pp. 59-60.

Maisnier-Patin S, Deschamps N, Tatini SR, Richard J, 1992. Inhibition of Listeria monocytogenes in Camembert cheese made with a nisin-producing starter. Lait 72:249-63.

Monfredini L, Settanni L, Poznanski E, Cavazza A, Franciosi E, 2012. The spatial distribution of bacteria in Grana cheese during ripening. Syst Appl Microbiol 35:54-63.

Morgan F, Bonnin V, Mallereau MP, Perrin G, 2001. Survival of Listeria monocytogenes during manufacture, ripening and storage of soft lactic cheese made from raw goat milk. Int $\mathrm{J}$ Food Microbiol 64:217-21.

O'Sullivan L, O'Connor EB, Ross RP, Hill C, 2006. Evaluation of live-culture producing lacticin 3147 as a treatment for the control of Listeria monocytogenes on the surface of smear-ripened cheese. J Appl Microbiol 100:135-43.

Scatassa ML, Gaglio R, Macaluso G, Francesca N, Randazzo W, Cardamone C, Di Grigoli A, Moschetti G, Settanni L, 2015. Transfer, composition and technological characterization of the lactic acid bacterial populations of the wooden vats used to produce traditional stretched cheeses. Food Microbiol 52:31-41.

Schillinger U, Lücke FK, 1989. Antibacterial activity of Lactobacillus sake isolated from meat. Appl Environ Microb 55:1901-6.

Schillinger U, Geisen R, Holzapfel WH, 1996. Potential of antagonistic microorganisms and bacteriocins for the biological preservation of foods. Trends 
Food Sci Tech 7:158-64.

Settanni L, Massitti O, Van Sinderen D, Corsetti A, 2005. In situ activity of a bacteriocin producing Lactococcus lactis strain. Influence on the interactions between lactic acid bacteria during sourdough fermentation. J Appl Microbiol 99:670-81.

Settanni L, Moschetti G, 2014. New trends in technology and identity of traditional dairy and fermented meat production processes: preservation of typicality and hygiene. Trends Food Sci Tech 37:51-8. Settanni L, Guarcello R, Gaglio R, Francesca N, Aleo A, Felis GE, Moschetti G, 2014. Production, stability, gene sequencing and in situ antiListeria activity of mundticin KS expressed by three Enterococcus mundtii strains. Food Control 35:311-22.
Walker SJ, Archer P, Banks JG, 1990. Growth of Listeria monocytogenes at refrigeration temperatures. J Appl Bacteriol 68:157-62.

WHO/FUN/FOS, 1995. Food technologies and public health. Available from http://www.who.int/foodsafety/publications/public-health/en/ 